\title{
Floristic patterns of the neotropical forests, savannas and scrublands with Trithrinax campestris (Arecaceae) in central Argentina
}

\author{
Sebastián R. Zeballos ${ }^{1}$, Marcelo R. Cabido ${ }^{1}$, Juan J. Cantero ${ }^{1,2}$, Alicia T.R. Acosta ${ }^{4}$, \\ M. Virginia Palchetti ${ }^{1}$, Juan Argañaraz ${ }^{5}$, Paula I. Marcora ${ }^{1}$, Paula A. Tecco ${ }^{1,3}$, Ana Ferreras ${ }^{1}$, \\ Guillermo Funes ${ }^{1,3}$, Victoria M. Vaieretti ${ }^{1}$, Georgina Conti ${ }^{1}$, Melisa A. Giorgis ${ }^{1,3}$ \\ 1 Instituto Multidisciplinario de Biología Vegetal (CONICET-UNC), Córdoba, Argentina \\ 2 Departamento de Biología Agrícola, Facultad de Agronomía y Veterinaria, UNRC, Córdoba, Argentina \\ 3 Facultad de Ciencias Exactas, Físicas y Naturales, Universidad Nacional de Córdoba, Córdoba, Argentina \\ 4 Dipartimento di Scienze, Università degli Studi di Roma Tre, Roma, Italy \\ 5 Instituto de Altos Estudios Espaciales Mario Gulich (CONAE-UNC), CONICET, Córdoba, Argentina \\ Corresponding author: Melisa A. Giorgis (mgiorgis@imbiv.unc.edu.ar)
}

Academic editor: F. Fernández-González • Received 7 October 2020 • Accepted 17 December 2020 Published 17 February 2021

\begin{abstract}
Aims: Trithrinax campestris is one of the palm species with the southernmost distribution in the Neotropics. Despite that the vegetation types in which T. campestris occurs are nowadays heavily threatened by land use and land cover changes, their floristic composition and structure are still to be documented. In order to characterize T. campestris habitats, the aim of this study was to describe the floristic composition of the vegetation types in which this palm occurs and their relationships with different environmental factors.
\end{abstract}

Study area: The survey was conducted in central Argentina in an area comprising the southern extreme of the distribution of T. campestris in the following phytogeographic areas: Espinal, Lowland and Mountain Chaco.

Methods: Following the Braun-Blanquet approach we collected 92 floristic relevés recording a total of 601 vascular plant species. Vegetation was classified through the ISOPAM hierarchical analysis. Bioclimatic and elevation data were related to the floristic data through the ISOMAP ordination. Remote-sensed images (Landsat TM, ETM+ and OLI) were used to characterize the fire frequency in the 92 stands.

Results: Four vegetation types that differed in floristic composition and in diagnostic species were discriminated: 1.1 Celtis tala/Sida rhombifolia closed forest; 1.2 Aspidosperma quebracho-blanco/Prosopis kuntzei open forest; 2.1 Jarava pseudoichu/Vachellia caven open savanna; and 2.2 Acalypha variabilis/Nassella cordobensis scrubland. The ISOMAP ordination showed that differences in floristic composition were related to elevation, topography and climatic variables. Out of the 92 stands, only 21 showed the occurrence of fires during the period 1999-2018.

Conclusions: Our results evidenced that vegetation types (forests, savannas and scrublands) comprising T. campestris developed in a wide range of environmental conditions. This is the first study that focuses on all vegetation types in which T. campestris occurs in central Argentina and it is relevant for conservation and sustainable management of the only native palm species in the flora of this part of the country.

Taxonomic reference: Catálogo de las Plantas Vasculares del Cono Sur (Zuloaga et al. 2008) and its online update (http://www.darwin.edu.ar).

Abbreviations: ISOMAP = isometric feature mapping; ISOPAM = isometric partitioning around medoids. 


\section{Keywords}

Chaco, chorotype, endemism, environmental variable, Espinal, floristic composition, palm, species richness, vegetation type

\section{Introduction}

Trithrinax Martius is a neotropical genus of palms (Arecaceae) distributed in the subtropical and warm temperate region of South America, from almost sea level up to an elevation of 1,500 m (Cano et al. 2013). It belongs to the subfamily Coryphoideae and to the tribe Cryosophileae (Dransfield et al. 2005, 2008), and occurs in Brazil, Argentina, Bolivia, Paraguay, and Uruguay (Henderson et al. 1995; Dransfield et al. 2008; Pintaud et al. 2008; Zuloaga et al. 2008; Gaiero et al. 2012). Trithrinax comprises three species (T. brasiliensis, T. schizophylla and T. campestris), widely distributed in different habitats and vegetation types. The northern limit of its distribution lies in Santa Cruz Department, Bolivia, where T. schizophylla occurs, while in the southern extreme of its range, in central Argentina and Uruguay, T. campestris is found (Cano et al. 2013). Trithrinax species are more tolerant to drought and lower temperatures than other species of palms (Boyer 1992; Riffle and Craft 2003; Meerow 2005). Particularly, it has been documented that T. campestris may resist even less than $-10^{\circ} \mathrm{C}$ (Meerow 2005), which may explain its distribution at higher latitudes.

The distribution area of $T$. campestris is mainly restricted to central Argentina (Cano et al. 2013) where the vegetation types in which the palm occurs, belong to the Espinal and Chaco phytogeographical provinces (Cabrera 1976). Previous studies report the presence of this species in various vegetation types with different soil and climatic conditions and different disturbance histories (Sayago 1969; Luti et al. 1979). In each habitat the importance of T. campestris ranges from some scattered, isolated individuals, to locally dense populations where the species becomes dominant in the community (Sayago 1969). From the phytogeographic point of view, Kurtz (1904), Sayago (1969) and Cabido et al. (2018) reported the occurrence of $T$. campestris in forests, grasslands or in savannas of the Lowland Chaco area, while Giorgis et al. (2017) recognized the presence of the palm as a co-dominant and subordinate species across different vegetation types in the Mountain Chaco. Within the Espinal phytogeographic province, Lewis and Collantes (1973) identified a floristic district based in part on the occurrence of this species. More recently, Lewis et al. (2009) also reported the occurrence of some isolated patches of Espinal forests comprising T. campestris in the eastern area of Córdoba province, central Argentina. However, none of these studies performed on Chaco or Espinal reported the complete floristic composition of the patches in which this palm occurs. Moreover, the effect of those factors that have been previously reported as major drivers influencing the distribution of palm vegetation types worldwide (Eiserhardt et al. 2011) such as climatic (e.g., water and temperature seasonality related variables), edaphic and anthropic (e.g., agriculture, fire and herbivory) have not been explored comprehensively for this palm species (Sayago 1969; Luti et al. 1979). Therefore, the vegetation types in which T. campestris occurs, their composition and structure, as well as the relationship with the main environmental variables are still to be documented.

As many palms worldwide, T. campestris is a keystone species for local people that traditionally use the leaves and spines to make handicrafts such as baskets and a variety of objects (Moraes 2001; Cano 2014). Moreover, this palm is being evaluated for the production of biofuels. At the same time, vegetation types with T. campestris are threatened because many habitats previously occupied by communities with palms are currently replaced by soybean and corn crops and also by pastures (Cano 2014; Mendoza et al. 2016; and personal observation by the authors). Knowledge of the effects of human activities (i.e., fire and grazing) on the population dynamics of T. campestris, as well as its germination ecology, is still preliminary. Cano (2014) reported an evident lack of seedlings and saplings due to anthropogenic fires and cattle grazing, while Mendoza et al. (2016) highlighted the lack of new palm seedlings related to extremely low seed germination observed in field and laboratory experiments. The persistent leafsheaths protect the stems of adult individuals what may be an adaptation to anthropogenic originated fires (Cano et al. 2013). Individuals of T. campestris seen in the field frequently show fire marks in the naked stems which lose their sheath layers (Cano et al. 2013 and personal observations by the authors). However, seedlings are not resistant to fire episodes, showing that fire may represent an important threat for the long-term survival for Trithrinax wild populations (Cano et al. 2013). In the last decades mature specimens have been exported to European countries for use in gardening (in 2003 the exportation of T. campestris generated an income of 600,000 USD; SENASA, Argentina, http://www.senasa.gob.ar/senasa-comunica/ noticias/). Furthermore, the invasion by exotic species represents an additional potential threat for the vegetation types in which T. campestris occurs (Giorgis et al. 2017; Cabido et al. 2018; Zeballos et al. 2020). Cano et al. (2013) defined the conservation status of T. campestris as vulnerable, mainly due to habitat destruction and conversion to agriculture, and further insights on vegetation types with T. campestris are urgently needed to develop proper conservation and management strategies.

This study aimed to describe for the first time the whole floristic composition of vegetation types of the main habitats in which T. campestris occurs in central Argentina. Since disturbance may have introduced dramatic changes 
in the physiognomy of vegetation, we also explored the patterns of life forms distribution. In addition, and taking into account that the habitats in which T. campestris occurs involve different phytogeographic units, we also establish the proportion of chorotypes and endemic species present, as well as the origin of all the taxa recorded in each vegetation type. Finally, the association between the floristic composition and the main environmental variables (i.e., bio-climatic, topographic and edaphic) and fire frequency, were assessed.

\section{Methods}

\section{Study area and vegetation survey}

The survey was conducted in central Argentina, Córdoba province, covering ca. $161,000 \mathrm{~km}^{2}$ (Figure 1). Sampling sites were distributed in habitats where the presence of T. campestris had been reported in previous works by Kurtz (1904), Sayago (1969), Lewis and Collantes (1973) and Luti et al. (1979), as well as in sites where specimens deposited in the Herbarium of the National University of Córdoba (CORD) had been collected. The study area is partially included in the Espinal phytogeographic province and the Western (Lowland) and Mountain Chaco districts according to the phytogeographic scheme of Argentina (Cabrera 1976). Following the Biogeographic Map of South America by Rivas-Martínez et al. (2011), our vegetation types are mainly included in the South Chacoan Province within the Chacoan Region (Chaqueña), and in the Xerophytic Pampean Region. The eastern extreme of the study area belongs to the Espinal (Lewis and Collantes 1973; Cabrera 1976; Zeballos et al. 2020), and is characterized by seasonally dry subtropical forests and woodlands distributed on lowlands with deep and well to imperfectly drained soils, in the proximity of the Pampean phytogeographic province. The northern extreme occupies part of the Lowland Chaco ecosystem (Western Chaco District sensu Cabrera, 1976) with xerophytic forests on well to excessively drained soils and part of the Mountain Chaco District (Cabrera 1976) occupying low hillsides and slopes with shallow and rocky substrates and small valley bottoms with deeper soils. Finally, the western extreme of the study area also belongs to the Mountain Chaco District; the landscape is dominated by open woodlands and scrublands on dry gentle and steep slopes alternating with flat areas ("pampas") with deeper soils and narrow valley bottoms likely to suffer occasional flooding. At the beginning of the $20^{\text {th }}$ century, the study area was covered by xerophytic forests dominated by Aspidosperma quebracho-blanco, Schinopsis lorentzii and species of Prosopis in the lowlands. In the mountains, the landscape was dominated by a mosaic of woodlands, shrublands and grasslands and the main tree species were Lithraea molleoides, Schinopsis marginata and Ruprechtia apetala (Kurtz 1904; Sayago 1969; Luti et al. 1979). Decades of exploitation of Chaco and Espinal forests driven by timber and firewood

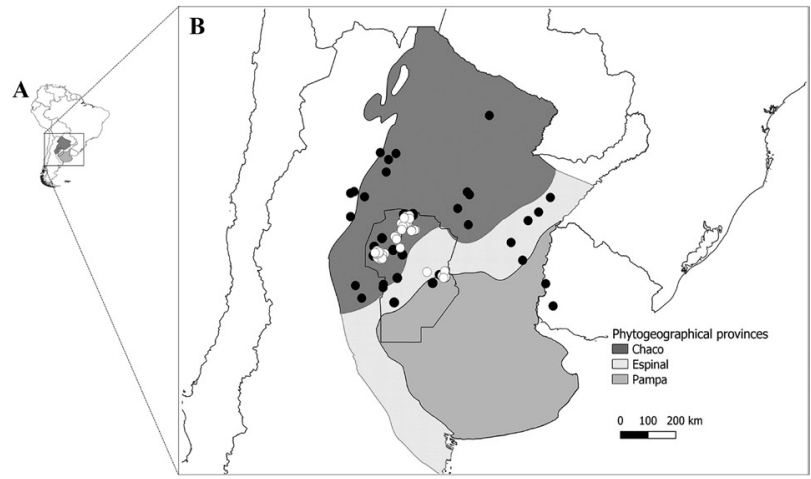

Figure 1. A Location of the study area (Córdoba province) in South-America; B Location of Córdoba province in central Argentina and overall distribution of Trithrinax campestris (black dots) in Argentina and Uruguay (according to Cano et al. (2013) and Flora australis database) and sample plots (relevés; white dots) collected in this study in Córdoba province. The location of Chaco (dark grey), Espinal (light grey), and Pampa (intermediate grey) phytogeographic provinces in central and northern Argentina are depicted based on Cabrera (1976).

extraction (Schofield and Bucher 1986) and the advances of the agricultural frontier (Arturi 2005; Guida-Johnson and Zuleta 2013; Fehlenberg et al. 2017) have altered the original distribution patterns of vegetation types (Zak et al. 2008; Hoyos et al. 2013; Agost 2015; Giorgis et al. 2017; Cabido et al. 2018; Garachana et al. 2018; Kowaljow et al. 2018; Zeballos et al. 2020).

The study area is characterized by two main geomorphologic units: an old Cambric mountain system comprising three main ranges and lowlands filled with Pleistocene and Holocene sediments, distributed both to the east and west of the mountains (Carignano et al. 2014). The study area comprises a climatic gradient from subtropical in the lowland Espinal and Chaco areas (200 to $400 \mathrm{~m}$ ), to warm temperate in the northern and western mountain localities $(500$ to $1200 \mathrm{~m})$. Average annual temperature ranges from 17 to $20^{\circ} \mathrm{C}$ in the flat areas to 13 to $14^{\circ} \mathrm{C}$ in the northern and western hills (Cabido et al. 1998). Average annual rainfall is highest in the north-east, ranging from 700 to $900 \mathrm{~mm}$, decreasing to less than $600 \mathrm{~mm}$ to the west of the study area. Over the whole area, more than $80 \%$ of the rainfall is concentrated from October to March (warm season in Southern Hemisphere).

The vegetation survey was designed to cover the geographic, topographic and ecological variability of vegetation types in which $T$. campestris is present regardless of its abundance (Figure 2). Sampling followed the Zürich-Montpellier School of phytosociology (Braun-Blanquet 1932), and comprised 92 georeferenced $20 \times 20 \mathrm{~m}^{2}$ plots. In each plot, all vascular plants were recorded and species cover was estimated using the cover-abundance scale of Braun-Blanquet (1932) $(+=<1 \%$ cover; $1=1-5 \% ; 2=6-25 \% ; 3=26-50 \% ; 4=51-75 \%$; $5=76-100 \%)$. The height and cover of the tree, shrub and herb layers were visually estimated. Species nomenclature, 

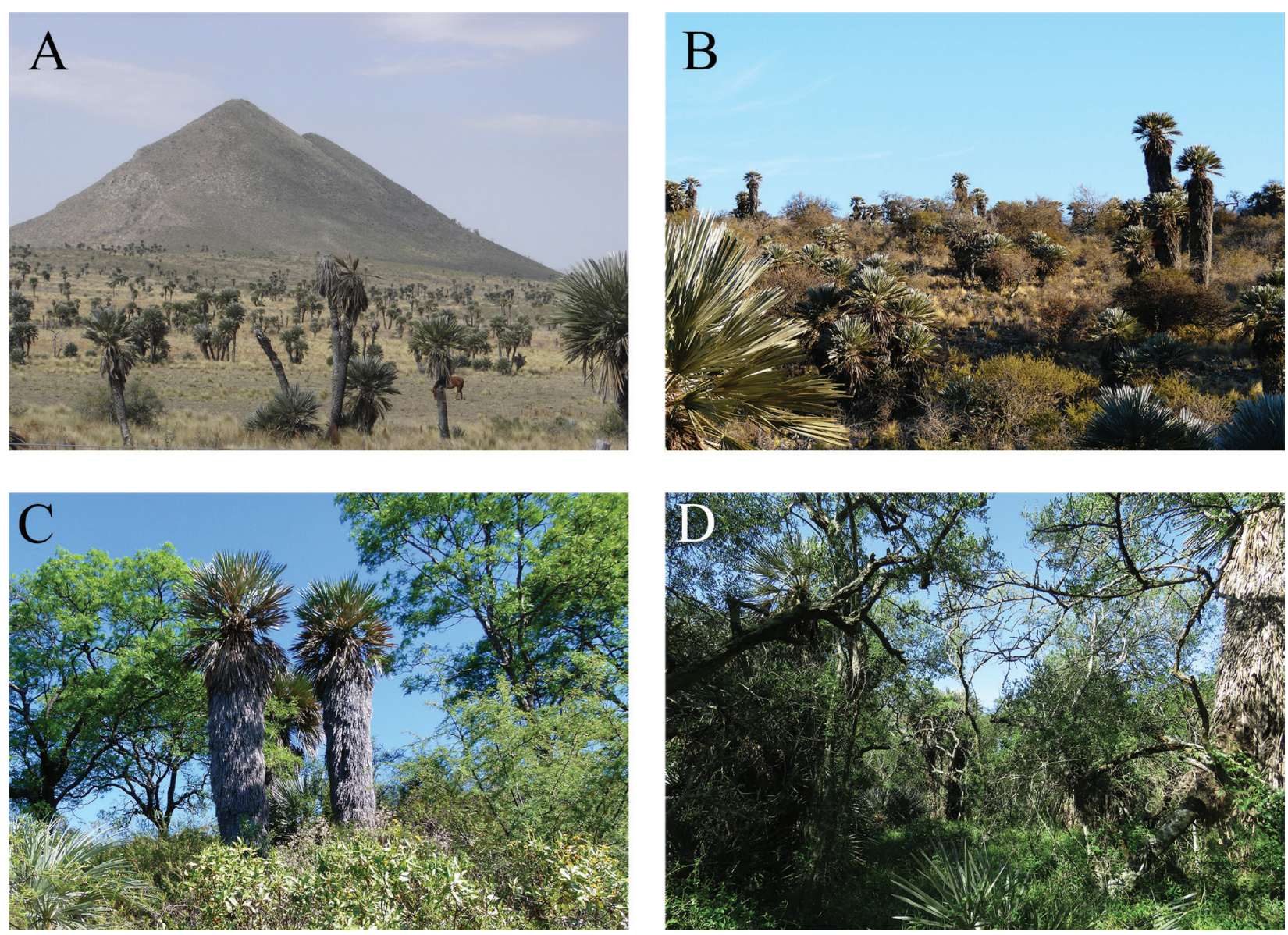

Figure 2. Examples of vegetation types comprising Trithrinax campestris in the study area in central Argentina. A Palm savanna with $T$. campestris in a matrix of grasslands on gentle hillside slopes; B Scrubland dominated by Vachellia caven and T. campestris on rocky soils; C Mountain Chaco forest dominated by Schinopsis marginata with scattered individuals of T. campestris on steep mountain slopes; and D Espinal forest with Celtis tala, Prosopis nigra and T. campestris on deep soils in lowland areas.

their distributional range and species origin (i.e., native or exotic) followed the catalogue of vascular plants of the Southern Cone (Zuloaga et al. 2008) and its online update (http://www.darwin.edu.ar/). Endemic taxa at the national and local levels followed Giorgis et al. (under review). Endemic at the local levels means endemic species restricted to the study area and surrounding provinces (mainly Córdoba and San Luis). Fourteen out of the 92 vegetation plots are registered in the Global Index of Vegetation-Plot Database (Dengler et al. 2011; http://www. givd.info) under ID SA-AR-002.

To assess the main trends of species distribution patterns and their representation in the study area, species chorotypes (groups of species with a similar distribution), were assigned following the criteria proposed by Cabido et al. (1998) and Zeballos et al. (2020): Southern-Brazilian (1), Chaquenian (2), Low Mountain Chaco (3), Arid Chaco and Monte (4) and Exotic (5). Additionally, the mean percentage of each chorotype per plot as well as the mean species richness and number of exotics per relevé were calculated. Life forms followed Zeballos et al. (2020) thus sorted as: cactus (c), climber (cl), epiphyte (e), fern (f), grass (g), graminoid $(\mathrm{gr})$, herb $(\mathrm{h})$, parasite $(\mathrm{p})$, palm $(\mathrm{pl})$, shrub (s) and tree $(\mathrm{t})$.

\section{Environmental variables}

Bioclimatic variables and elevation were interpolated from the WorldClim database (http://www.worldclim. org; Fick and Hijmans 2017), at a spatial resolution of 30 seconds $\left(c a .1 \mathrm{~km}^{2}\right)$ for continental South America. As the main bioclimatic variables that constrain the distribution of palm species and communities worldwide are related to water availability and temperature (Eiserhardt et al. 2011) the following variables were selected: Precipitation of the Wettest Quarter(PWeQ), Minimum Temperature of the Coldest Month (MTCM), Precipitation Seasonality (PS), Precipitation of the Wettest Month (PWeM), Annual Precipitation (AP), and Precipitation of the Driest Quarter (PDQ) (see O'Donnell and Ignizio 2012 for details concerning all the bioclimatic variables). To obtain data on topographic and edaphic variables for each plot (slope and organic matter content of the surface soil layer), all the 92 relevés were plotted on digitalized maps of the soils of Córdoba province provided at two different scales (i.e., 1:500,000 and 1:50,000) (Gorgas and Tassile 2006; http:// visor.geointa.inta.gob.ar/? $\mathrm{p}=857)$. The $1: 50,000$ scale was preferentially used, but some information gaps at this 
scale were completed with data provided by the map at 1:500,000. Both maps depict soil cartographic units and describe the internal heterogeneity of each unit through representative soil profiles providing an analysis of their chemical and physical properties.

Following Argañaraz et al. (2015a) and Argañaraz et al. (2020) the fire history frequency was characterized for the 92 sampling sites. Time series of Landsat TM, ETM+, and OLI images (30 $\mathrm{m}$ of spatial resolution), covering the study area, acquired between 1999 and 2018 were used. This fire database was derived automatically using ABAMS (Automatic Burned Area Mapping Software), a tool based on the algorithm proposed by Bastarrika et al. (2011) and updated versions implemented in Google Earth Engine. We considered any continuous burned patch as a single fire event except when the intensity of the burned signal was markedly different. Specifically, fire frequency is the number of times that a plot was burned for the period of time considered. The minimum mapping unit of the fire database is of 5 ha (Argañaraz et al. 2015a). We converted vector layers of burned areas to raster format as binary layers (burned or unburned) and determined the fire frequency for the 92 sites.

\section{Data analyses}

The ISOmetric feature mapping and Partition Around Medoids (ISOPAM) ordination and classification method were employed to analyze the 92 relevés. This analysis was used to detect the major vegetation types and their corresponding diagnostic species groups (Schmidtlein et al. 2010; Černý et al. 2015; Cabido et al. 2018). Hierarchical ISOPAM was run on the Bray-Curtis dissimilarity matrix. This matrix was constructed with the floristic table after Braun-Blanquet scores were transformed to the central class values (Kent 2012). The maximum number of clusters on each hierarchical level was arbitrarily set to ten and standardized $G$ statistics to five. For each vegetation type, diagnostic species were selected using the phi coefficient of fidelity (Chytrý et al. 2002). Those species with phi $\geq$ 0.1 and a statistically significant association $(p<0.001)$ with a particular vegetation type according to Fisher's exact test, were considered as diagnostic. These analyses were performed in the JUICE 7.0 program (Tichý 2002). Each vegetation type was named after the first two species that showed: 1$)$ phi $\geq 0.2$ and a statistically significant $(p<0.001)$ association with a given vegetation type; and 2 ) constancy $>30 \%$. The vegetation matrix was ordinated through isometric feature mapping (ISOMAP; Tenembaum et al. 2000; Černý et al. 2015), using the number of neighbors to the optimal value from the first hierarchical level of the ISOPAM classification.

Incidence-based rarefaction and extrapolation $(\mathrm{R} / \mathrm{E})$ curves using sample size-based and coverage-based methods were performed to evaluate whether plant species from the different vegetation types classified by the ISOPAM method were well represented (Budka et al. 2018;
Zeballos et al. 2020). Chao2, Jackknife 1 and Jackknife 2 non-parametric estimators for incidence data were used to estimate the total number of species that would be present in each vegetation type. Further, the coverage estimate for each plant community is given because it represents the estimated fraction of the entire population of individuals in the community that belong to the species represented in the sample. Non-parametric estimators for incidence data, and incidence-based rarefaction and extrapolation (R/E) curves were performed using the SpadeR and iNEXT R-packages (Chao and Chiu 2016), respectively. Analyses of variance were performed in order to evaluate the differences in mean species richness, mean percentage of each chorotype per relevé as well as the differences in the mean species richness and number of exotics per relevé among vegetation types. In all cases, the normality of the data and the homoscedasticity of variances were checked and when these requirements were not met, the data were natural $\log$ transformed. The relationship between the floristic composition and fire frequency as well as bioclimatic and edaphic variables was assessed through the envift function from the vegan R-package (http://CRAN.R-project.org/ package $=$ vegan). Bioclimatic and elevation data extractions were conducted using the extract function. Those variables with the highest squared correlation coefficient were related to the ISOMAP ordination. Furthermore, to evaluate how the vegetation structure of stands, as well as T. campestris cover, were affected by fire frequency, ANOVAs were performed. All analyses and graphs were performed in R version 3.5.1 ( $\mathrm{R}$ Core Team 2018).

\section{Results}

\section{Floristic composition}

A total of 601 vascular plant species and infraspecific taxa (555 natives, including 68 endemics and 46 exotics), distributed among 77 families and 333 genera, were recorded in the 92 relevés (Table 1 and see also Suppl. material 1: Table S1.1). The most common families were Poaceae (108 species), Asteraceae (104), and Fabaceae (43), which together accounted for $42.4 \%$ of all species. Other common families were Euphorbiaceae (27 species), Solanaceae (26), Malvaceae (24), Cactaceae and Verbenaceae (22 species each). The most common genera were Baccharis, (13 species), Euphorbia (12), Solanum (11), Tillandsia (10), Nassella and Croton (8 species each). The predominant life forms were herbs (264 species), followed by grasses (108), shrubs (88), climbers (46), trees (27) and cacti (22). The most prominent chorotype was the Southern-Brazilian $(56.08 \pm 11.73 \%$ of all species, mean plus standard deviation), followed by the Chaquenian (29.67 $\pm 13.15 \%)$, the Low Mountain Chaco (11.08 $\pm 5.65 \%)$, and the Arid Chaco and Monte $(0.12 \pm 0.43 \%)$ chorotypes. Exotics were represented by $3.05 \pm 3.19 \%$ of all species. The overall cover of T. campestris in the 92 relevés ranged from less than $1 \%$ to almost $40 \%$. 
Table 1. Synoptic table of the vegetation types classified by ISOPAM analysis showing the percentage constancy, mean Braun-Blanquet cover (as superscript) and phi values based on 92 relevés collected in Córdoba province, central Argentina. Species are sorted by decreasing fidelity within each vegetation type. Dark, medium and light grey indicates phi $\geq 0.3$, phi $\geq 0.2$ and phi $\geq 0.1$, respectively. Vegetation type codes: 1.1 Celtis tala/Sida rhombifolia closed forest; 1.2 Aspidosperma quebracho-blanco/Prosopis kuntzei open forest; 2.1 Jarava pseudoichu/Vachellia caven open savanna; 2.2 Acalypha variabilis/Nassella cordobensis scrubland. Life forms (LF): c: cactus; cl: climber; e: epiphyte; f: fern; g: grass; gr: graminoid; h: herb; p: parasite; pl: palm; s: shrub; t: tree. Chorotypes (CT): (1) Southern-Brazilian, (2) Chaquenian, (3) Low Mountain Chaco, (4) Arid Chaco and Monte, (5) Exotic. Symbols: ${ }^{\circ}$ : endemics at local level; *: endemics at the national level.

\begin{tabular}{|c|c|c|c|c|c|c|}
\hline \multirow[b]{2}{*}{ Vegetation type } & \multirow[t]{2}{*}{ LF } & \multirow[t]{2}{*}{ CT } & \multicolumn{2}{|c|}{ Cluster 1} & \multicolumn{2}{|c|}{ Cluster 2} \\
\hline & & & 1.1 & 1.2 & 2.1 & 2.2 \\
\hline Number of relevés & & & 15 & 9 & 40 & 28 \\
\hline Trithrinax campestris & $\mathrm{pl}$ & 2 & $100^{2}$ & $100^{1}$ & $100^{2}$ & $100^{1}$ \\
\hline \multicolumn{7}{|l|}{ Diagnostic species } \\
\hline Sida rhombifolia & $\mathrm{h}$ & 1 & $66.7^{1}$ & $11.1^{+}$ & $7.5^{+}$ & $3.6^{+}$ \\
\hline Celtis tala & $\mathrm{t}$ & 1 & $100^{2}$ & $77.8^{2}$ & $55^{1}$ & $46.4^{1}$ \\
\hline Nassella hyalina & $\mathrm{g}$ & 1 & $40^{2}$ & & $5^{1}$ & \\
\hline Rivina humilis & $\mathrm{h}$ & 1 & $66.7^{1}$ & $11.1^{+}$ & $5^{+}$ & $3.6^{+}$ \\
\hline Dicliptera squarrosa & $\mathrm{h}$ & 1 & $53.3^{2}$ & & $12.5^{+}$ & $10.7^{+}$ \\
\hline Malvastrum coromandelianum & $\mathrm{h}$ & 1 & $73.3^{1}$ & $22.2^{+}$ & $20^{+}$ & $10.7^{+}$ \\
\hline Holmbergia tweedii & s & 2 & $33.3^{1}$ & & & \\
\hline Schinus longifolius & s & 2 & $46.7^{1}$ & $11.1^{+}$ & $10^{+}$ & $3.6^{+}$ \\
\hline Capsicum chacoënse & s & 2 & $40^{+}$ & & $7.5^{+}$ & \\
\hline Cyperus hermaphroditus & gr & 1 & $26.7^{+}$ & & & \\
\hline Araujia odorata & $\mathrm{cl}$ & 1 & $53.3^{+}$ & $22.2^{+}$ & $5^{+}$ & $3.6^{+}$ \\
\hline Prosopis kuntzei & $\mathrm{t}$ & 2 & & $88.9^{2}$ & & \\
\hline Sarcomphalus mistol & $\mathrm{t}$ & 2 & $6.7^{+}$ & $88.9^{2}$ & & \\
\hline Jarava ichu var. ichu & g & 3 & & $55.6^{2}$ & $10^{2}$ & \\
\hline Aspidosperma quebracho-blanco & $\mathrm{t}$ & 2 & $13.3^{1}$ & $100^{1}$ & $10^{+}$ & \\
\hline Vachellia aroma & s & 2 & & $66.7^{1}$ & $7.5^{1}$ & $3.6^{+}$ \\
\hline Senegalia praecox & $\mathrm{t}$ & 2 & $13.3^{2}$ & $88.9^{1}$ & $2.5^{+}$ & $3.6^{1}$ \\
\hline Mimosa detinens & s & 2 & & $55.6^{+}$ & & \\
\hline Deinacanthon urbanianum & e & 2 & $6.7^{1}$ & $88.9^{+}$ & & \\
\hline Monteverdia spinosa & $\mathrm{s}$ & 2 & $6.7^{+}$ & $77.8^{+}$ & $5^{+}$ & \\
\hline Nicotiana glauca & s & 1 & & $44.4^{+}$ & & \\
\hline Govinia paraguayensis & g & 2 & & $44.4^{+}$ & & $3.6^{+}$ \\
\hline Croton lachnostachyus & s & 3 & $33.3^{1}$ & $77.8^{1}$ & $17.5^{+}$ & $10.7^{+}$ \\
\hline Tillandsia aizoides* & e & 2 & $13.3^{+}$ & $55.6^{+}$ & $10^{+}$ & \\
\hline Castela coccinea & $\mathrm{t}$ & 2 & & $55.6^{+}$ & & \\
\hline Opuntia quimilo & c & 2 & & $66.7^{+}$ & & $3.6^{+}$ \\
\hline Cleistocactus baumannii & c & 2 & & $44.4^{+}$ & & \\
\hline Atamisquea emarginata & s & 2 & & $44.4^{+}$ & & \\
\hline Pseudabutilon pedunculatum & $\mathrm{h}$ & 2 & $13.3^{+}$ & $66.7^{+}$ & $2.5^{+}$ & \\
\hline Leptochloa crinita & g & 2 & $6.7^{+}$ & $44.4^{+}$ & & \\
\hline Harrisia pomanensis & c & 2 & & $44.4^{+}$ & & $3.6^{+}$ \\
\hline Synedrellopsis grisebachii & $\mathrm{h}$ & 2 & & $66.7^{+}$ & $5^{+}$ & $7.1^{+}$ \\
\hline Melica argyrea & g & 1 & & $33.3^{+}$ & & \\
\hline Jarava pseudoichu & g & 3 & $46.7^{1}$ & & $85^{3}$ & $71.4^{2}$ \\
\hline Prosopis campestris ${ }^{\circ}$ & $\mathrm{t}$ & 2 & & & $32.5^{2}$ & $3.6^{+}$ \\
\hline Condalia microphylla* & s & 2 & $33.3^{1}$ & $100^{+}$ & $77.5^{1}$ & $25^{1}$ \\
\hline Lippia turbinata f. turbinata & $\mathrm{s}$ & 2 & $20^{+}$ & $11.1^{1}$ & $70^{1}$ & $50^{1}$ \\
\hline Vachellia caven & $\mathrm{s}$ & 1 & $53.3^{1}$ & $11.1^{1}$ & $97.5^{2}$ & $100^{2}$ \\
\hline Acalypha variabilis & $\mathrm{h}$ & 1 & $26.7^{1}$ & & $45^{1}$ & $96.4^{2}$ \\
\hline Nassella cordobensis* & g & 3 & & & $15^{1}$ & $64.3^{1}$ \\
\hline Krapovickasia flavescens & $\mathrm{h}$ & 1 & $6.7^{+}$ & $11.1^{+}$ & $45^{+}$ & $89.3^{1}$ \\
\hline Aristida circinalis & $g$ & 1 & & & $2.5^{+}$ & $28.6^{1}$ \\
\hline Sporobolus indicus & g & 1 & $6.7^{1}$ & & $17.5^{+}$ & $60.7^{1}$ \\
\hline Aristida adscensionis & g & 2 & & $11.1^{+}$ & $40^{1}$ & $67.9^{1}$ \\
\hline Condalia montana* & $\mathrm{t}$ & 3 & $20^{2}$ & $11.1^{+}$ & $20^{1}$ & $64.3^{1}$ \\
\hline
\end{tabular}

\begin{tabular}{lcccccc}
\hline & LF & CT & Cluster 1 & \multicolumn{2}{c}{ Cluster 2 } \\
\hline Vegetation type & & & $\mathbf{1 . 1}$ & $\mathbf{1 . 2}$ & $\mathbf{2 . 1}$ & $\mathbf{2 . 2}$ \\
Tripogonella spicata & $\mathrm{g}$ & 1 & & $11.1^{+}$ & $5^{+}$ & $39.3^{1}$ \\
Baccharis linearifolia & $\mathrm{s}$ & 1 & & & $15^{+}$ & $53.6^{+}$ \\
Microchloa indica var. indica & $\mathrm{g}$ & 1 & & $11.1^{+}$ & $10^{+}$ & $46.4^{1}$ \\
Schizachyrium salzmannii & $\mathrm{g}$ & 1 & & & $2.5^{+}$ & $25^{1}$ \\
Andropogon ternatus & $\mathrm{g}$ & 1 & & & $2.5^{1}$ & $25^{1}$ \\
Eustachys retusa & $\mathrm{g}$ & 1 & & $11.1^{+}$ & $60^{1}$ & $78.6^{1}$ \\
Gomphrena perennis var. perennis & $\mathrm{h}$ & 1 & $6.7^{1}$ & & $10^{1}$ & $42.9^{1}$ \\
Glandularia peruviana & $\mathrm{h}$ & 1 & & $11.1^{+}$ & $45^{+}$ & $71.4^{+}$ \\
Margyricarpus pinnatus & $\mathrm{S}$ & 1 & & & $15^{+}$ & $57.1^{+}$ \\
Glandularia venturii & $\mathrm{h}$ & 2 & & & $15^{+}$ & $57.1^{+}$ \\
\hline
\end{tabular}

\section{Vegetation classification}

The vegetation matrix was classified by the ISOPAM analysis into two main clusters (C1 and $\mathrm{C} 2$ ) and each cluster was further partitioned into two vegetation types (Table 1). Species constancy and average cover data are reported in synoptic Table 1 and also in the extended Suppl. material 1: Table S1.1. Cluster 1 comprised relevés collected mainly in the plains located to the east and north of the study area (Espinal and the Lowland Chaco, respectively), while Cluster 2 included relevés distributed predominantly, but not exclusively, in low mountain ranges and valley bottoms located to the north and west of the area (Lowland Chaco and the Mountain Chaco, respectively). Although the sample-sizebased rarefaction showed that the curves of the four vegetation types had not yet reached the asymptote (Figure 3A), the observed species richness reached a high percentage of the species estimated using the non-parametric estimators (Table 2). The coverage-based rarefaction curves suggested that the four vegetation types identified were well represented since the sample coverage percentage showed values equal or higher than 0.85 in all types (Figure 3B, C; Table 2).

Table 2. Species observed $\left(\mathrm{S}_{\mathrm{obs}}\right)$ and non-parametric estimators of species richness plus standard error for incidence data for each vegetation type. Vegetation type codes: 1.1 Celtis tala/Sida rhombifolia closed forest; 1.2 Aspidosperma quebracho-blanco/Prosopis kuntzei open forest; 2.1 Jarava pseudoichu/Vachellia caven open savanna; 2.2 Acalypha variabilis/Nassella cordobensis scrubland. Estimators: Chao2-bc: a bias-corrected form for the Chao2 estimator; Jackknife 1: Estimator that use the frequency of uniques; Jackknife 2: Estimators that use the frequencies of uniques and duplicates; and $C$. hat: Sample coverage index.

\begin{tabular}{lcccc}
\hline $\begin{array}{c}\text { Non-parametric } \\
\text { estimators }\end{array}$ & $\mathbf{1 . 1}$ & $\mathbf{1 . 2}$ & $\mathbf{2 . 1}$ & $\mathbf{2 . 2}$ \\
\hline $\mathrm{S}_{\text {obs }}$ & 250 & 163 & 444 & 399 \\
Chao2-bc & $344.72 \pm 24.06$ & $220.80 \pm 19.35$ & $553 \pm 25.17$ & $568.29 \pm 39.99$ \\
Jackknife 1 & $351.73 \pm 14.02$ & $219.89 \pm 10.37$ & $570.75 \pm 15.82$ & $527.25 \pm 15.87$ \\
Jackknife 2 & $400.33 \pm 23.25$ & $249.25 \pm 16.67$ & $625.75 \pm 26.96$ & $606.93 \pm 26.90$ \\
C. hat & 0.86 & 0.88 & 0.95 & 0.94 \\
\hline
\end{tabular}

Descriptions of the vegetation types are given below:

Cluster 1: Comprises two vegetation types distributed mainly in the lowlands of the Espinal phytogeographical 

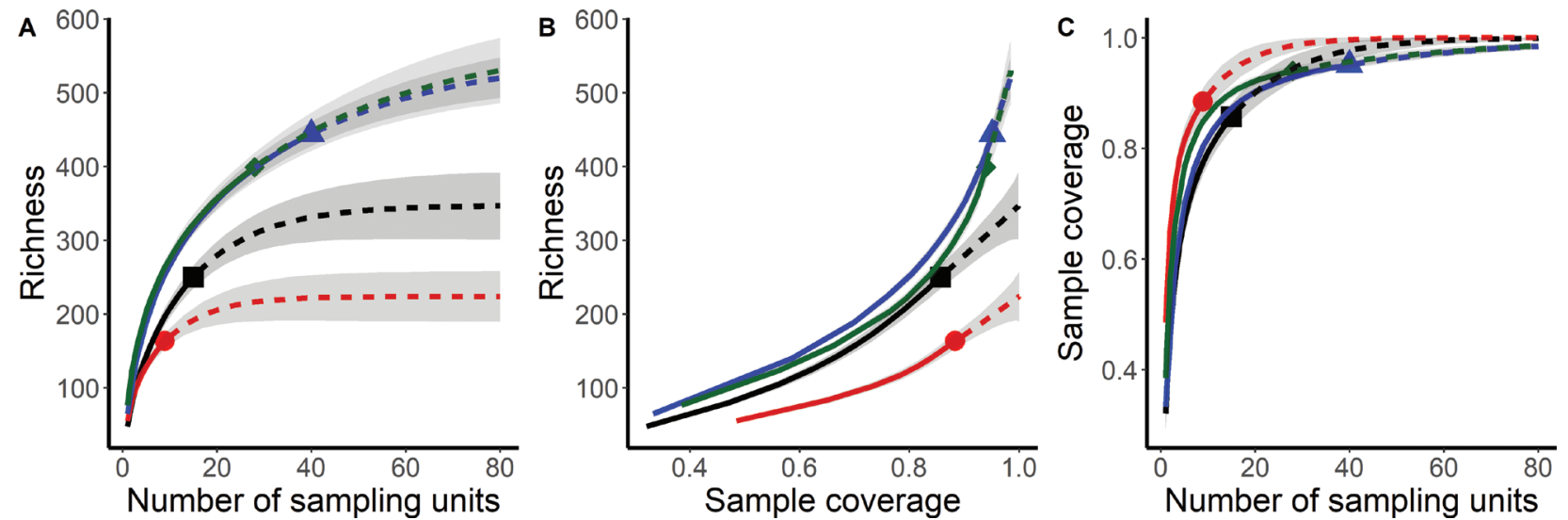

Figure 3. A Sample-size-based; B Coverage-based rarefaction and extrapolation sampling curves for species richness; C Sample completeness curves for each vegetation type. Solid line segments indicate rarefaction and dotted line segments indicate extrapolation (up to a maximum sample size of 40 ), while shaded areas indicate $95 \%$ confidence intervals (based on a bootstrap method with 100 replications). Colours and symbols: black square, 1.1 Celtis tala/Sida rhombifolia closed forest; red circle, 1.2 Aspidosperma quebracho-blanco/Prosopis kuntzei open forest; blue triangle, 2.1 Jarava pseudoichu/Vachellia caven open savanna; green diamond, 2.2 Acalypha variabilis/Nassella cordobensis scrubland.

province (and marginally in the adjacent Pampean territory) (Vegetation type 1.1) and the Western Chaco District (Vegetation type 1.2) in the north-east and north of the study area, respectively.

1.1 Celtis tala/Sida rhombifolia closed forest. Forests with a canopy height of $7.21 \pm 0.39 \mathrm{~m}$, dominated by a group of tree species typical of the Espinal forests such as Celtis tala, Geoffroea decorticans and Prosopis nigra. The tree layer showed the highest average percent cover value among the four vegetation types described $(60.2 \pm$ $7.65 \%$; mean plus standard error), followed by the herb layer with an average cover of $59.3 \pm 8.34 \%$ and a height of $0.59 \pm 0.07 \mathrm{~m}$, while the shrub layer exhibited a height of $2.64 \pm 0.25 \mathrm{~m}$ and the lowest average cover (33 $\pm 5.97 \%)$. Trithrinax campestris reached its highest average cover in this vegetation type $(17.48 \pm 4.12 \%)$ and co-dominated the tree and/or the shrub layer in some of the relevés (e.g., in some of them T. campestris showed a cover of $38 \%$ ). The tree Celtis tala together with some shrubs such as Schinus longifolius and Capsicum chacoense, the herb Rivina humilis, the grass Nassella hyalina and the climber Araujia odorata were diagnostic for this vegetation type (Table 1).

This vegetation type occurred mainly in the northeastern plains of the study area on deep soils but some stands were also found on the northern and western mountains occupying valley bottoms and gentle slopes, always on deep soils. In mountain valley bottoms with poor drainage or even very occasional flooding, T. campestris may also form pure stands. A total of 231 (213 natives and 18 exotics) species were recorded in this vegetation type, of which 19 are endemic (17 at the national and two at the local levels). The mean species richness per relevé was $47.3 \pm 3.31$. Among life forms, herbs (93 species, 37.2\%) jointly with shrubs and grasses (46 species each, $18.4 \%$ each), were the most abundant, followed by climbers (24 species, 9.6\%) and trees (22 species, $8.8 \%$ ).
1.2 Aspidosperma quebracho-blanco/Prosopis kuntzei open forest. Open forest with a tree layer cover of $30.67 \pm$ $9.94 \%$ and a height of $6.06 \pm 0.95 \mathrm{~m}$. A dense shrub layer $(59.44 \pm 4.29 \%)$ with a height of $3.31 \pm 0.3 \mathrm{~m}$ and a cover of the herb layer of $55.56 \pm 6.48 \%$ and a height of $0.56 \pm$ $0.02 \mathrm{~m}$ were recorded. Trithrinax campestris was a subordinated to other species and generally with low mean cover values (5.34 $\pm 1.85 \%)$. Several tree species like Aspidosperma quebracho-blanco, Prosopis kuntzei, Sarcomphalus mistol, Senegalia praecox and shrubs such as Vachellia aroma, Mimosa detinens, Castella coccinea, Atamisquea emarginata, Monteverdia spinosa, were local dominants and the diagnostic species for this type (Table 1). Also, diagnostics were the succulent cacti Opuntia quimilo, Cleistocactus baumannii and Harrisia pomanensis, as well as the $\mathrm{C}_{3}$ tussock grass Jarava ichu var. ichu.

This vegetation type usually forms isolated patches surrounded by soybean and corn crops in the lowlands of the northern part of the study area. A total of 153 (146 natives and seven exotics) species were recorded in this vegetation type of which 10 are endemic (eight at the national and two at the local levels). The mean species richness per relevé was $54.8 \pm 3.24$. The most abundant life forms were herbs ( 57 species, $34.9 \%$ ), shrubs ( 28 species, $17.2 \%$ ), grasses (32 species, 19.6\%), trees (14 species, 8.6\%) and climbers (13 species, $7.9 \%$ ).

Cluster 2: This Cluster includes two vegetation types distributed mainly in low mountain slopes and valley bottoms located in the Mountain Chaco District in the north and west of the study area.

2.1 Jarava pseudoichu/Vachellia caven open savanna. Open savannas with a high grass and herb cover (average cover and height of the herbaceous layer were 78.28 \pm $3.59 \%$ and $0.74 \pm 0.02 \mathrm{~m}$, respectively). The average cover 
of the tree and shrub layers was low $(14.15 \pm 2.16 \%$ and $34.3 \pm 2.69 \%$, respectively) while their height also showed low values $(4.64 \pm 0.33$ and $3.31 \pm 0.1 \mathrm{~m}$, for the tree and shrub layers, respectively). Trithrinax campestris density varied from only scattered individuals to denser patches in almost pure stands, reaching an average cover of 14.44 $\pm 2.11 \%$. The $\mathrm{C}_{3}$ grass Jarava pseudoichu and the shrubs Prosopis campestris, Condalia microphylla, Lippia turbinata fo. turbinata and Vachellia caven were diagnostic species for this vegetation type (Table 1).

This vegetation type was widely distributed across gentle slopes and valley bottoms mostly in the mountains of the northern part of the study area though some stands are located to the west, on both gentle relief and more steep topography. In some stands, the dominant vegetation was an open scrubland dominated by Vachellia caven, while on slopes of the mountains to the west of the area remnants of Low Mountain Chaco Forest, dominated by Schinopsis marginata, Lithraea molleoides and Ruprechtia apetala, with only sparse individuals of T. campestris, were found. A total of 406 (375 natives and 31 exotic species) species were recorded of which 39 are endemics (31 at the national and eight at the local levels). The mean species richness per relevé was $64.3 \pm 2.28$. Herbs (197 species, $44.3 \%$ ), grasses (87 species, $19.5 \%$ ) and shrubs (68 species, $15.3 \%)$ were the most common life forms.

2.2 Acalypha variabilis/Nassella cordobensis scrubland. Open scrubland with an almost continuous grass and herb cover (the average cover of the herbaceous layer was $70.68 \pm 4.73 \%$ with a height of $0.71 \pm 0.05 \mathrm{~m}$ ). Despite that in some stands on rocky substrate the shrub cover may increase, the average cover and height of this layer were medium to low $(35.18 \pm 3.30 \%$ and $2.34 \pm 0.14 \mathrm{~m}$, respectively). Tree cover and height were the lowest among the four types described $(5.54 \pm 2.65 \%$ and $3.46 \pm 0.5 \mathrm{~m}$, respectively). Trithrinax campestris was present generally with sparse individuals and showed the lowest average cover reported in this study $(3.78 \pm 0.92 \%)$. Among the diagnostic species, the small shrub Acalypha variabilis showed the highest constancy and average cover (Table 1). The list of diagnostic species is completed with the $\mathrm{C}_{3}$ grass Nasella cordobensis, the $\mathrm{C}_{4}$ grasses Aristida circinalis, Sporobolus indicus, Aristida adscensionis, Microchloa indica, Tripogonella spicata, Schizachyrium salzmannii, Andropogon ternatus, Eustachys retusa and some shrubs and herbs.

This vegetation type was distributed on gentle to steep slopes in the mountains of the northern part of the study area, though a few stands were also recorded in the mountains to the west. Soils were shallow and the percentage of bare rock was generally considerable. A total of 400 (385 natives and 15 exotics) species were recorded in this community, of which 47 are endemic (35 at the national and 12 at the local levels). The mean species richness per relevé was $76.5 \pm 3.06$. Herbs (181 species, $45.2 \%$ ), grasses (77 species, $19.25 \%$ ) and shrubs (53 species, $13.2 \%$ ) were the most abundant life forms.

\section{Richness and chorotype patterns among vege- tation types}

The total number of vascular plant species per relevé ranged between 29 and 103, and the mean species richness per relevé differed significantly among vegetation types $\left(\mathrm{F}_{3,88}=15.04 ; p=0.001\right)$. The Acalypha variabilis/ Nassella cordobensis scrubland showed the highest mean species richness per relevé (Table 3), while the Celtis talal Sida rhombifolia closed forest had the lowest richness; the other two vegetation types showed intermediate values. We recorded 52 endemic species at national level and 16 at local level; only 5 endemic species (Gymnocalycium mostii; Gymnocalycium capillense; Apurimacia dolichocarpa; Alternanthera pumila and Trichocline plicata) were restricted to the study area and surroundings. Significant differences in the representativeness of the different chorotypes were observed among the vegetation types, with the exception of the Arid Chaco and Monte chorotype (Table 3). The vegetation types differed significantly in their Southern-Brazilian chorotype representativeness $\left(\mathrm{F}_{3,88}=23.34 ; p=0.001\right)$ as well as in the Chaquenian chorotype $\left(\mathrm{F}_{3,88}=40.73 ; p<\right.$ 0.001). The Southern-Brazilian chorotype was the best represented with the exception of the Aspidosperma quebracho-blanco/Prosopis kuntzei open forest in which the Chaquenian chorotype exhibited the highest percentage of species (Table 3). Species of the Southern-Brazilian chorotype showed the highest proportion in the two vegetation types of Cluster 2 and in Celtis tala/Sida rhombifolia closed forest. The Arid Chaco and Monte chorotype was less represented in the four vegetation types (i.e., less than $1 \%$ on each one), and without significant differences between them $\left(\mathrm{F}_{3,88}=1.46 ; p=0.23\right)$. The Low Mountain Chaco chorotype also showed differences between vegetation types $\left(\mathrm{F}_{3,88}=9.34 ; p=<0.001\right)$ with the highest values in both vegetation types of Cluster 2 (Table 3 ). The number of exotic species, as well as the proportion of exotics per relevé, showed significant differences between vegetation

Table 3. Species richness, number of exotics per plot and mean percentage of each chorotype per plot (plus standard error) for each vegetation types classified by ISOPAM analysis. Different letters denote statistically significant differences as identified by ANOVA post-hoc LSD Fisher test. Vegetation type codes: 1.1 Celtis tala/Sida rhombifolia closed forest; 1.2 Aspidosperma quebracho-blanco/ Prosopis kuntzei open forest; 2.1 Jarava pseudoichu/Vachellia caven open savanna; 2.2 Acalypha variabilis/Nassella cordobensis scrubland.

\begin{tabular}{lcccc}
\hline \multicolumn{1}{c}{ Vegetation type } & $\mathbf{1 . 1}$ & $\mathbf{1 . 2}$ & $\mathbf{2 . 1}$ & $\mathbf{2 . 2}$ \\
\hline Species richness & $47.33 \pm 3.31 \mathrm{a}$ & $54.89 \pm 3.24 \mathrm{ab}$ & $64.3 \pm 2.28 \mathrm{~b}$ & $76.57 \pm 3.06 \mathrm{c}$ \\
Number of exotics & $2.2 \pm 0.55 \mathrm{ab}$ & $1.11 \pm 0.39 \mathrm{bc}$ & $2.4 \pm 0.3 \mathrm{a}$ & $1.07 \pm 0.19 \mathrm{c}$ \\
per plot & & & & \\
Southern-Brazilian & $55.51 \pm 3.43 \mathrm{~b}$ & $34.32 \pm 2.61 \mathrm{c}$ & $56.82 \pm 1.38 \mathrm{~b}$ & $62.69 \pm 1.22 \mathrm{a}$ \\
Chaquenian & $31.68 \pm 3.3 \mathrm{~b}$ & $58.21 \pm 2.92 \mathrm{a}$ & $28.31 \pm 1.31 \mathrm{~b}$ & $21.95 \pm 1.2 \mathrm{c}$ \\
Low Mountain & $7.77 \pm 1.58 \mathrm{c}$ & $5.65 \pm 0.73 \mathrm{c}$ & $11.38 \pm 0.75 \mathrm{~b}$ & $14.21 \pm 1.01 \mathrm{a}$ \\
Chaco & & & & \\
Arid Chaco and & $0.23 \pm 0.16 \mathrm{a}$ & $0.32 \pm 0.06 \mathrm{a}$ & $0.08 \pm 0.06 \mathrm{a}$ & $0.04 \pm 0.04 \mathrm{a}$ \\
Monte & & & & \\
Exotic & $4.08 \pm 1.35 \mathrm{a}$ & $1.49 \pm 0.47 \mathrm{bc}$ & $3.4 . \pm 0.47 \mathrm{ab}$ & $1.11 \pm 0.22 \mathrm{c}$ \\
\hline
\end{tabular}


types $\left(\mathrm{F}_{3,88}=6.52 ; p=0.0005\right.$ and $\mathrm{F}_{3,88}=4.4 ; p=0.006$, respectively) with the highest values observed in the Celtis tala/Sida rhombifolia closed forest and the Jarava pseudoichu/Vachellia caven vegetation type (Table 3 ).

\section{Vegetation types, environmental variables and fire frequency}

The ISOMAP ordination (Figure 4) showed that differences in floristic composition were related to elevation (Elev; $\left.r^{2}=0.44, p=0.001 ;\right)$, minimum temperature of the coldest month (MTCM; $r^{2}=0.40, p=0.001$ ), precipitation of the driest quarter (PDQ; $r^{2}=0.37, p=0.001$ ), precipitation of the wettest month (PWeM; $r^{2}=0.37, p=0.001$ ), annual precipitation (AP; $\left.r^{2}=0.37, p=0.001\right)$, precipitation seasonality (PS; $r^{2}=0.33, p=0.001$ ), precipitation of the wettest quarter (PWeQ; $r^{2}=0.31, p=0.001$ ), organic matter content of the topsoil (OM; $\left.r^{2}=0.29, p=0.001\right)$ and slope $\left(r^{2}=0.28, p=0.001\right)$. Elevation was the most important factor in relation to composition, with both vegetation types included in Cluster 2 characterized by mean elevations higher than $900 \mathrm{~m}$, while elevation ranged from

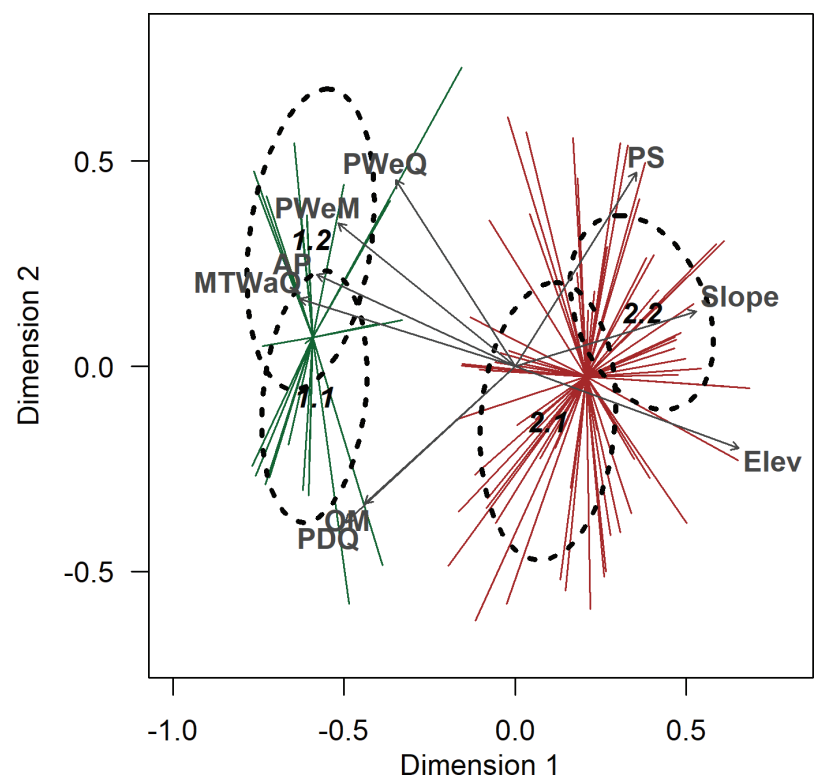

Figure 4. Isometric feature mapping plot (ISOMAP), based on Bray-Curtis dissimilarity of 92 relevés $\times 601$ plant species matrix for those vegetation types that include Trithrinax campestris in central Argentina. Vegetation type codes: 1.1 Celtis tala/Sida rhombifolia closed forest; 1.2 Aspidosperma quebracho-blanco/Prosopis kuntzei open forest; 2.1 Jarava pseudoichu/Vachellia caven open savanna; 2.2 Acalypha variabilis/Nassella cordobensis scrubland. Environmental variables abbreviations: Elev: Elevation; MTCM: Minimum Temperature of Coldest Month; PWeQ: Precipitation of the Wettest Quarter; PS: Precipitation Seasonality, PWeM: Precipitation of the Wettest Month; AP: Annual Precipitation; $P D Q$ : Precipitation of the Driest Quarter; OM: Organic matter. Colours: green, Cluster 1; red, Cluster 2.
340 to $436 \mathrm{~m}$ in average in Cluster 1 . This elevation gradient mirrored trends in temperature related variables (e.g., minimum temperature of coldest month). The vegetation types included in Cluster 1 occupied warmer areas with higher precipitations with $c a .100 \mathrm{~mm}$ difference respect to Cluster 2. Slope exhibited an appreciable range of variation between both Clusters and was steeper in low mountain areas (Cluster 2). Organic matter content of the surface soil layer showed higher average values in Cluster 1.

Out of the 92 stands, only 21 showed the frequency of fires during the period 1999-2018. Overall, the fire frequency was not related to the floristic composition $\left(r^{2}=0.04, p=0.12\right)$. Eighteen sites were burned only once while three sites were burned three times during the period analyzed. Those stands that belong to the vegetation types of Clusters 2 showed a higher fire frequency since 13 out of 40 stands were burned in the Jarava pseudoichul Vachellia caven open savanna while 4 out of 28 stands were burned in the Acalypha variabilis/Nassella cordobensis scrubland. The vegetation types of Cluster 1 showed just two stands burned each. However, the four vegetation types did not differ in their fire frequency $\left(\mathrm{F}_{3,84}=2.16\right.$; $p=0.09)$. Furthermore, the vegetation structure of stands (i.e., the percentage cover of each vegetation layer) of the different vegetation types did not show any significant differences between unburned and burned stands according to their tree $\left(\mathrm{F}_{3,84}=0.81 ; p=0.49\right)$, shrub $\left(\mathrm{F}_{3,84}=0.39\right.$; $p=0.76)$ and herb $\left(\mathrm{F}_{3,84}=0.18 ; p=0.9\right)$ layers cover as well as in T. campestris cover $\left(\mathrm{F}_{3,84}=0.46 ; p=0.71\right)$.

\section{Discussion}

In this study we describe for the first time the complete floristic composition of the main vegetation types in which T. campestris occurs in central Argentina. Our results evidenced that either as isolated individuals intermingled in forests (Cluster 1), in savannas and scrublands (Cluster 2), or as denser populations (likely in both Clusters) (Table 1 and Figure 4), this palm is able to occupy sites with different topography and soils along a wide gradient of environmental conditions. This wide gradient of environmental conditions was already observed by former botanists who studied the flora in central Argentina more than one hundred years ago (Lorentz 1876; Kurtz 1904), and several decades before our survey (Sayago 1969; Luti et al. 1979); however, none of them included complete floristic inventories.

\section{Richness, endemism and chorological patterns among vegetation types}

Relevés included in Cluster 2 revealed higher mean species number if compared with Cluster 1 . The higher species richness recorded in vegetation types of Cluster 2 (Jarava pseudoichu/Vachellia caven open savanna and Acalypha variabilis/Nassella cordobensis scrubland) 
(Table 3), might reflect the topographic and edaphic heterogeneity observed in the Low mountain Chaco habitats occupied by these vegetation types. In mountain environments, topography may influence the distribution of plant species and vegetation types by modifying soil properties, exposure, and temperature, as well as vegetation physiognomy and dynamics (Svenning 2001; Eiserhardt et al. 2011). In contrast, both vegetation types included in Cluster 1 (Celtis tala/Sida rhombifolia closed forest and Aspidosperma quebracho-blanco/Prosopis kuntzei open forest), are distributed in more homogeneous landscapes found in the plains and flatlands of the Espinal and Chaco domains. Vegetation types in Cluster 2 are also richer in species than other woody communities of plains and low mountain habitats in central Argentina (Giorgis et al. 2017; Cabido et al. 2018; Zeballos et al. 2020). Similar patterns of higher species diversity reflecting habitat heterogeneity have been reported elsewhere in the world for different types of vegetation (Whittaker 1960; Coblentz and Riiters 2004; Kreft and Jetz 2007) and specifically for communities rich in palm species (Guimarães et al. 2002; Resende et al. 2013). An additional factor influencing local species richness may be the physiognomy of vegetation which, is the results of complex feedback between climate, topography and disturbance (i.e., fire and grazing) (Giorgis et al. 2017; Argañaraz et al. 2020). Vegetation types comprised in Cluster 1 exhibited higher tree canopy cover and the differences in their canopy openness could determine gradients of light affecting the distribution of species. Cluster 2, instead, comprised open savannas and scrublands allowing for more light availability at the shrub and herb layers (Figure 2), which may enhance plant species richness. Strong influence of light gradients through competition for light and shade tolerance has been reported in other biomes, especially in tropical forests (Carson and Schnitzer 2008), but at the moment, our evidence is scarce and needs further research.

In addition to the variations in species richness among the vegetation types (Table 3), differences in the composition of endemic species were also observed. Vegetation types included in Cluster 2 showed the highest numbers of endemic species both at the national and local levels. Jarava pseudoichu/Vachellia caven open savanna and Acalypha variabilis/Nassella cordobensis scrubland comprised 8 and 12 endemism at local level, respectively, which evidenced the high natural value of these vegetation types and their importance for biodiversity conservation. The valuable pattern of endemism reflected in our data could be explained through the isolating effect of mountains with respect to lowlands; recent studies report a clear correlation between plant endemism and mountain isolation (Steinbauer et al. 2016; Camacho-Sanchez et al. 2019). Despite our findings, the distribution of many taxa is still scarcely known in Argentina and further floristic and chorological studies could change the status of many plant species.

The Southern-Brazilian and Chaquenian chorotypes were dominant in all the four vegetation types described (Table 3). The same pattern has also been reported by
Cabido et al. (1998) and Zeballos et al. (2020) for woody vegetation types from central Argentina including mainly lowland vegetation types. The predominance of these chorotypes is not surprising since our study area includes sedimentary plains and low mountain habitats. Moreover, there are not significant barriers to the dispersal of taxa distributed in the eastern and northeastern area of the country (Southern-Brazilian chorotype) and from the northern flatlands of the Great Chaco in the northern region of Argentina, but also Bolivia and Paraguay (Chaquenian chorotype) (Fuentes and Navarro 2000; Steininger et al. 2001; Navarro et al. 2006). Many of the species reported in our survey with a Southern-Brazilian distribution have also been mentioned by Rodriguez et al. (2017) as components of Butia yatay palm groves and gallery forests in northeastern Argentina, where T. campestris is a subordinate element.

The overall number of exotics in our survey is lower with respect to those reported in previous floristic studies from central Argentina (Giorgis and Tecco 2014; Cabido et al. 2018; Zeballos et al. 2020). The number of exotic species ranged from 7 to 31 among the four vegetation types, with Jarava pseudoichu/Vachellia caven open savanna showing the highest record, while the mean number of exotics per plot was maximum in Celtis tala/Sida rhombifolia closed forest. Note that in this vegetation type even some exotics are considered diagnostic species (e.g., the grass Chloris gayana and the tree Morus alba). This higher exotic occurrence may be explained by the earlier expansion of agriculture in this area in comparison with that of the Aspidosperma quebracho-blanco/Prosopis kuntzei open forest, where the introduction of intensive agriculture is more recent (Zak et al. 2008; Cabido et al. 2018; Zeballos et al. 2020).

\section{Vegetation types and environmental factors}

Within Cluster 1, trends in floristic composition were mainly related to annual rainfall, other precipitation parameters associated to it, and the minimum temperature of the coldest month (Figure 4). On the other side, in Cluster 2 composition was mainly driven by elevation and topography but also by precipitation seasonality. Celtis tala/Sida rhombifolia closed forest and Aspidosperma quebracho-blanco/Prosopis kuntzei open forest occurred at the warmest part of the study area where annual rainfall is higher, whereas Jarava pseudoichu/Vachellia caven open savanna and Acalypha variabilis/Nassella cordobensis scrubland occupied the highest and coldest habitats in premontane hills to the north and west of the study area. Areas at higher elevations are characterized not only by lower temperatures, but also by different topographic conditions and rocky soils that which may avoid the establishment of species from the lowland Espinal and Chaco areas (Cabido et al. 2018; Zeballos et al. 2020).

Despite of the environmental differences between the vegetation types described, our results showed that 
T. campestris can grow in a wide range of environmental conditions. In line with our results, previous studies dealing with palm communities in tropical and subtropical areas have emphasized the occurrence of palm species in different habitat types, such as floodplains, terraces, swamps, premontane hills, and even dry lands (Navarro 1997; Navarro et al. 2006; Balslev et al. 2010; Eiserhardt et al. 2011; Resende et al. 2013; Rodríguez et al. 2017). We should note that this species grows in warm temperate areas and sites not necessarily subjected to temporary or permanent flooding, as has been observed in many species of the family Arecaceae (Eiserhardt et al. 2011). Bjorholm et al. (2006) suggested that for species within the Coryphoideae subfamily, the present-day environmental regional factors have low explanatory power in its current distribution while non-environmental regional factors and/or long-term disturbance factors might have historically constrained their distribution. As Dalle et al. (2002) and Svenning et al. (2004) remarked, some palm species may be associated with disturbances that occurred more than 20 years ago. In this sense, a climatic reconstruction of central Argentina not only observed the presence of silicophytolith of the Arecaceae family but also registered a peak of higher aridity and warm climate experimented 1,600 years ago (Giorgis et al. 2015). These climatic conditions might have allowed that $T$. campestris reached the southernmost distribution in central Argentina.

Several authors have pointed to the effect of range management (e.g., fire and cattle grazing) on the physiognomy and composition of vegetation types comprising other Argentinian palm species (Morello and Adamoli 1974; Biani et al. 2007; Cabral and Castro 2007; Batista et al. 2014). Fire is a common and important disturbance driver in central Argentina and particularly in the study area (Argañaraz et al. 2015 a, b, 2020). Observations in the early works by Sayago (1969) and Luti et al. (1979), as well as more recent findings by Giorgis et al. (2013), Carbone et al. (2017) and Kowaljow et al. (2018), highlight the effect of fires on the structure and composition of Chaco vegetation in Córdoba. However, we registered a low fire frequency in the plots surveyed (i.e., 21 out of the 92 sampling sites were burned) at least for a period of twenty years. This result suggests that other drivers, such as land use change and grazing may be more important determining the structure and floristic patterns of those vegetation types in which T. campestris grows naturally. Nevertheless, our data concerning the effect of fires are only preliminary and longer time series of fire frequency are needed.

\section{Conclusions and further perspectives}

This study provides a detailed analysis of the vegetation types comprising T. campestris, the only native palm species in the flora from central Argentina. Moreover, our study highlights that T. campestris can grow in a variety of community types with different environmental conditions. These results are essential to develop adequate conservation strategies and useful for the sustainable management of this endangered species. It is accepted that the current distribution of palms is limited by climatic conditions prevailing during the cold season (Walther 2002), and that under warming scenarios some palm species may be extending their ranges into higher latitudes and altitudes (Walther et al. 2007; Giorgis et al. 2015). However, to our knowledge, there is no information about the behavior that $T$. campestris may show under changing scenarios of temperature and rainfall neither about its regeneration niche. Preliminary field observations suggest that a high number of seedlings could be associated with higher tree canopy cover while in more open sites the lack of regeneration could be related to more vulnerable populations. Future studies should extend the floristic survey to other areas in which the vegetation types comprising T. campestris have been reported (Cano et al. 2013; 2014), especially in San Luis and Santiago del Estero provinces, also located in central Argentina (see Figure 1). Similarly, future successional and demographic studies should complement our survey in order to give a more complete picture of the real conservation status of the species and of the vegetation types in which it occurs.

\section{Data availability}

A subset of the plots is included in the database SA-AR-002 - Vegetation of Central Argentina(Dengler et al. 2011; http://www.givd.info). The remaining subset will be included in the same database in 2021. The data are also available from the Corresponding author upon reasonable request.

\section{Author contributions}

SRZ, MRC, MAG, designed the survey; MAG, MRC, JJC, ATRA, PIM, did the field work; SRZ, MRC performed data analysis; SRZ, MAG, MRC, ATRA, JJC wrote the original manuscript; JA analyzed fire data; MVP, JA, PIM, PAT, AF, GF, MVV, GC contributed substantially to the final writing of the manuscript and in the interpretation of results.

\section{Acknowledgements}

We thank Ángela Cano for advice on the overall distribution of T. campestris. This research was partially supported by the Consejo Nacional de Investigaciones Científicas y Técnicas (CONICET), the Ministerio de Ciencia y Tecnología de la Provincia de Córdoba (MINCyT - Córdoba, No. 000007/2019), the Secretaría de Ciencia y Tecnología (SECyT - UNC), the Universidad Nacional de Río Cuarto and Neotropical Grassland Conservancy. 


\section{References}

Argañaraz JP, Pizarro GG, Zak M, Bellis LM (2015a) Fire regime, climate, and vegetation in the sierras de Córdoba, Argentina. Fire Ecology 11: 55-73. https://doi.org/10.4996/fireecology.1101055

Argañaraz JP, Pizarro GG, Zak M, Landi MA, Bellis LM (2015b) Human and biophysical drivers of fires in semiarid Chaco mountains of central Argentina. Science of the Total Environment 520: 1-12. https:// doi.org/10.1016/j.scitotenv.2015.02.081

Argañaraz JP, Cingolani AM, Bellis LM, Girogis MA (2020) Fire incidence along an elevation gradient in the mountains of central $\mathrm{Ar}$ gentina. Ecología Austral 30: 268-281. https://doi.org/10.25260/ EA.20.30.2.0.1054

Balslev H, Eiserhardt W, Kristiansen T, Pedersen D, Grandez C (2010) Palms and palm communities in the upper Ucayali river valley - a little known region in the Amazon basin. Palms 54: 57-72.

Bastarrika A, Chuvieco E, Pilar Martín M (2011) Automatic Burned Land Mapping from MODIS time series images: Assessment in Mediterranean Ecosystems. IEEE Transactions on Geoscience and Remote Sensing 49: 3401-3413. https://doi.org/10.1109/TGRS.2011.2128327

Batista WB, Rolhauser AG, Biganzoli F, Burkart SE, Goveto L, Maranta A, Genoveva Pignataro A, Morandeira NS, Rabadán M (2014) Las comunidades vegetales de la sabana del parque nacional el palmar (Argentina). Darwiniana, nueva serie 2: 5-38. https://doi.org/10.14522/ darwiniana.2014.21.569

Biani NB, Middleton J, Romano MC (2007) Applied biodiversity conservation linked to sustainable development in a Chaco ecosystem in northern Santa Fe province, Argentina. International Journal of Environmental, Cultural, Economic and Social Sustainability 2: 53-62. https://doi.org/10.18848/1832-2077/CGP/v02i07/54300

Bjorholm S, Svenning JC, Baker WJ, Skov F, Balslev H (2006) Historical legacies in the geographical diversity patterns of New World palm (Arecaceae) subfamilies. Botanical Journal of the Linnean Society 151: 113-125. https://doi.org/10.1111/j.1095-8339.2006.00527.x

Boyer K (1992) Palms and Cycads Beyond the Tropics. Palm and Cycad Societies of Australia, Milton, AU, 150 pp.

Braun-Blanquet J (1932) Plant sociology. The study of plant communities. McGraw-Hill, New York, US.

Brown JH (2001) Mammals on mountainsides: elevational patterns of diversity. Global Ecology and Biogeography 10: 101-109. https://doi. org/10.1046/j.1466-822x.2001.00228.x

Budka A, Łacka A, Szoszkiewicz K (2018) Estimation of river ecosystem biodiversity based on the Chao estimator. Biodiversity and Conservation 27: 205-216. https://doi.org/10.1007/s10531-017-1429-2

Cabido M, Funes G, Pucheta E, Vendramini F, Díaz S (1998) A chorological analysis of the mountains from Central Argentina. Is all what we call Sierra Chaco really Chaco? Contribution to the study of the flora and vegetation of the Chaco. Candollea 53: 321-331.

Cabido M, Zeballos SR, Zak M, Carranza ML, Giorgis MA, Cantero JJ, Acosta AT (2018) Native woody vegetation in central Argentina: Classification of Chaco and Espinal forests. Applied Vegetation Science 21: 298-311. https://doi.org/10.1111/avsc.12369

Cabral EL, Castro M (2007) Palmeras argentinas, Guía para el reconocimiento. L.O.L.A, Buenos Aires, AR, 88 pp.

Cabrera AL (1976) Regiones fitogeográficas argentinas. In: Kugler WF (Eds) Enciclopedia argentina de agricultura y jardinería. Acme, Buenos Aires, AR, 1-85.
Camacho-Sanchez M, Hawkins MTR, Yu FTY, Maldonado JE, Leonard JA (2019) Endemism and diversity of small mammals along two neighboring Bornean mountains. PeerJ 7: e7858. https://doi. org/10.7717/peerj.7858

Cano A, Perret M, Stauffer FW (2013) A revision of the genus Trithrinax (Cryosophileae, Coryphoideae, Arecaceae). Phytotaxa 136: 1-53. https://doi.org/10.11646/phytotaxa.136.1.1

Cano A (2014) A subtropical quest to discover wild Trithrinax. Palms 52: 65-71.

Carbone LM, Aguirre-Acosta N, Tavella J, Aguilar R (2017) Cambios florísticos inducidos por la frecuencia de fuego en el Chaco Serrano. Boletín de la Sociedad Argentina de Botánica 52: 753-778. https:// doi.org/10.31055/1851.2372.v52.n4.18861

Carignano C, Kröhling D, Degiovanni S, Cioccale M (2014) Geomorfología Relatorio. XIX Congreso Geológico Argentino, Córdoba, AR. Carson WP, Schnitzer SA (2008) Tropical forest community ecology. Wiley-Blackwell, Chichester, UK.

Castellanos A, Ragonese AE (1949) Distribución geográfica de algunas palmas del Uruguay. Lilloa 20: 251-261.

Černý T, Kopecký M, Petřik P, Song J, Šrůtek M, Valachovič M, Altman J, Doležal J (2015) Classification of Korean forests: Patterns along geographic and environmental gradients. Applied Vegetation Science 18: 5-22. https://doi.org/10.1111/avsc.12124

Chao A, Chiu CH (2016) Nonparametric estimation and comparison of species richness. In: eLS (Encyclopedia of Life Sciences). John Wiley and Sons, Ltd, Chichester, UK. https://doi. org/10.1002/9780470015902.a0026329

Chytrý M, Tichý L, Holt J, Botta-Dukát Z (2002) Determination of diagnostic species with statistical fidelity measures. Journal of Vegetation Science 13: 79-90. https://doi.org/10.1111/j.1654-1103.2002.tb02025.x Coblentz DD, Riitters KH (2004) Topographic controls on the regional-scale biodiversity of the south-western USA. Journal of Biogeography 31: 1125-1138. https://doi.org/10.1111/j.13652699.2004.00981.x

Dalle SP, Lopez H, Diaz D, Legendre P, Potvin C (2002) Spatial distribution and habitats of useful plants: an initial assessment for conservation on an indigenous territory, Panama. Biodiversity and Conservation 11: 637-667. https://doi.org/10.1023/A:1015544325763

Dengler J, Jansen F, Glöckler F, Peet RK, De Cáceres M, Chytrý M, Ewald J, Oldeland J, Finckh M, .., Spencer N (2011) The Global Index of Vegetation-Plot Databases (GIVD): a new resource for vegetation science. Journal of Vegetation Science 22: 582-597. https://doi. org/10.1111/j.1654-1103.2011.01265.x

Dransfield J, Uhl NW, Asmussen CB, Baker WJ, Harley MM, Lewis CE (2005) A new phylogenetic classification of the palm family, Arecaceae. Kew Bulletin 60: 559-569.

Dransfield J, Uhl NW, Asmussen CB, Baker WJ, Harley MM, Lewis CE (2008) Genera Palmarum. Royal Botanic Gardens Kew, Richmond, UK. Eiserhardt WL, Svenning JC, Kissling WD, Balslev H (2011) Geographical ecology of the palms (Arecaceae): determinants of diversity and distributions across spatial scales. Annals of Botany 108: 1391-1416. https://doi.org/10.1093/aob/mcr146

Fick SE, Hijmans RJ (2017) WorldClim 2: new 1-km spatial resolution climate surfaces for global land areas. International Journal of Climatology 37: 4302-4315. https://doi.org/10.1002/joc.5086 
Gaiero P, Mazzella C, Vaio M, e Silva AB, Santiñaque FF, López-Carro B, Folle GA, Guerra M (2012) An unusually high heterochromatin content and large genome size in the palm tree Trithrinax campestris (Arecaceae). Australian Journal of Botany 60: 378-382. https://doi. org/10.1071/BT12029

Giorgis MA, Cingolani AM, Gurvich DE, Reynero N, Rufini S (2005) Diferencias en la estructura de la vegetación del sotobosque entre una plantación de Pinus taeda L. (Pinaceae) y un matorral serrano (Cuesta Blanca, Córdoba). Kurtziana 31: 39-49.

Giorgis MA, Cingolani AM, Cabido MR (2013) El efecto del fuego y las características topográficas sobre la vegetación y las propiedades del suelo en la zona de transición entre bosques y pastizales de las sierras de Córdoba, Argentina. Ecología Austral 48: 493-513. https://doi. org/10.31055/1851.2372.v48.n3-4.7555

Giorgis MA, Tecco PA (2014) Árboles y arbustos invasores de la Provincia de Córdoba (Argentina): una contribución a la sistematización de bases de datos globales. Boletín de la Sociedad Argentina de Botánica 49: 581-603. https://doi.org/10.31055/1851.2372.v49.n4.9991

Giorgis MA, Lopez ML, Rivero DE, Cingolani A M (2015) Cambios climáticos en las sierras de Córdoba (Argentina) durante el holoceno. Aportes a las reconstrucciones climáticas a través del análisis de silicofitolitos del sitio arqueológico El Alto 3. Boletín de la Sociedad Argentina de Botánica 50: 361-375. https://doi. org/10.31055/1851.2372.v50.n3.12526

Giorgis MA, Cingolani AM, Gurvich DE, Tecco PA, Chiapella J, Chiarini F, Cabido M (2017) Changes in floristic composition and physiognomy are decoupled along elevation gradients in central Argentina. Applied Vegetation Science 20: 558-571. https://doi.org/10.1111/ avsc. 12324

Gorgas JA, Tassile JL (2006) Recursos Naturales de la Provincia de Córdoba LOS SUELOS Nivel de reconocimiento 1: 500.000. INTA - Secretaría de Ambiente de Córdoba, Córdoba, AR.

Guimarães AJM, Araújo GM, Corrêa GF (2002) Estrutura fitossociológica em área natural e antropizada de uma vereda em Uberlândia, MG. Acta Botanica Brasilica 16: 317-329. https://doi.org/10.1590/S010233062013000100020

Henderson A, Galeano G, Bernal R (1995) Field guide to the palms of the Americas. Princeton University Press, Princeton, US. https://doi. org/10.1515/9780691197708

Hoyos LE, Cingolani AM, Zak MR, Vaieretti MV, Gorla DE, Cabido MR (2013) Deforestation and precipitation patterns in the Arid Chaco forests of central Argentina. Applied Vegetation Science 16: 260-271. https://doi.org/10.1111/j.1654-109X.2012.01218.x

Hoyos LE, Cabido MR, Cingolani AM (2018) A Multivariate Approach to Study Drivers of Land-Cover Changes through Remote Sensing in the Dry Chaco of Argentina. International Journal of Geo-Information 7: 170. https://doi.org/10.3390/ijgi7050170

Kent M (2012) Vegetation Description and Data Analysis - A Practical Approach (2 $2^{\text {nd }}$ ed.). Wiley-Blackwell, Oxford, UK.

Kowaljow E, Morales MS, Whitworth-Hulse JI, Zeballos SR, Giorgis MA, Rodríguez Catón M, Gurvich DE (2018) A 55-year-old natural experiment gives evidence of the effects of changes in fire frequency on ecosystem properties in a seasonal subtropical dry forest. Land degradation and development 30: 266-277. https://doi.org/10.1002/ldr.3219

Kreft H, Jetz W (2007) Global patterns and determinants of vascular plant diversity. Proceedings of the National Academy of Sciences 104: 5925-5930. https://doi.org/10.1073/pnas.0608361104
Kurtz F (1904) Flora de Córdoba. In: Río ME, Achával L (Eds) Geografía de la Provincia de Córdoba, Vol. 1. Compañía Sudamericana de Billetes de Banco, Buenos Aires, 270-343.

Lewis JP, Collantes MB (1973) El espinal periestépico. Ciencia e investigación 29: 360-377.

Lewis JP, Noetinger S, Prado DE, Barberis IM (2009) Woody vegetation structure and composition of the last relicts of Espinal vegetation in subtropical Argentina. Biodiversity and Conservation 18: 3615 3628. https://doi.org/10.1007/s10531-009-9665-8

Lorentz PG (1876) Cuadro de la vegetación de la República Argentina. Sociedad Anónima de Tipografía, Litografía y Fundición de Tipos, Buenos Aires, AR.

Luti R, Bertrán de Solís MA, Galera MF, Müller de Ferreira N, Berzal M, Nores M, Herrera MA, Barrera JC (1979) Vegetación. In: Vázquez J, Miatello R, Roquem M (Eds) Geografía Física de la provincia de Córdoba. Boldt, Buenos Aires, AR, 297-368.

Meerow AW (2005) Betrock's Cold Hardy Palms, $1^{\text {st }}$ ed. Betrock Information System, Florida city, US, 155 pp.

Mendoza C, Guardia L, Pagani A, Ovando G, Giardina E, Di Benedetto A (2016) Germination Limits Survival of Trithrinax campestris (Palm Tree) in Argentina. Journal of Agriculture and Ecology Research International 9: 1-11. https://doi.org/10.9734/JAERI/2016/27495

Moraes M (2001) Richness and utilization of palms in Bolivia-some essential criteria for their management. In: Biodiversity. Springer, Berlin, Heidelberg, DE, 269-278. https://doi.org/10.1007/978-3-662-06071-1_17

Morello J, Adámoli J (1974) Las grandes unidades de vegetación y ambiente del Chaco argentino. Segunda parte: Vegetación y Ambiente de la Provincia del Chaco. Serie Fitogeográfica N ${ }^{\circ}$ 13. INTA, Buenos Aires, AR, 130 pp.

Navarro G (1997) Contribución a la clasificación ecológica y florística de los bosques de Bolivia. Revista Boliviana de Ecología 2: 3-97.

Navarro G, Molina JA, Pérez de Molas L (2006) Classification of the forests of the northern Paraguayan Chaco. Phytocoenologia 36: 473508. https://doi.org/10.1127/0340-269X/2006/0036-0473

O’Donnell MS, Ignizio DA (2012) Bioclimatic predictors for supporting ecological applications in the conterminous United States. US Geological Survey Data Series 691. https://doi.org/10.3133/ds691

Pintaud JC, Galeano G, Balslev H, Bernal R, Borchsenius F, Ferreira E, de Granville JJ, Mejía K, Millán B, ..., Kahn F (2008) Las palmeras de América del Sur: diversidad, distribución e historia evolutiva. Revista Peruana de Biología 15: 7-29. https://doi.org/10.15381/rpb.v15i3.2662

R Core Team (2018) R: A language and environment for statistical computing. R Foundation for Statistical Computing, Vienna, Austria. https://www.R-project.org/

Resende ILM, Chaves LJ, Rizzo JA (2013) Floristic and phytosociological analysis of palm swamps in the central part of the Brazilian savanna. Acta Botanica Brasilica 27: 205-22. https://doi.org/10.1590/S010233062013000100020

Riffle RL, Craft P (2003) An Encyclopedia of Cultivated Palms. Timber Press, Oregon city, US, 528 pp.

Rivas-Martínez S, Navarro G, Penas A, Costa M (2011) Biogeographic map of South America. A preliminary survey. International Journal of Geobotanical Research 1: 21-40. https://doi.org/10.5616/ijgr110002

Rodríguez EE, Aceñolaza PG, Linares Perea E, Galán de Mera A (2017) A phytosociological analysis of Butia yatay (Arecaceae) palm groves and gallery forests in Entre Ríos, Argentina. Australian Journal of Botany 65: 183-202. https://doi.org/10.1071/BT16140 
Sayago M (1969) Estudio fitogeográfico del norte de Córdoba. Boletín Academia Nacional de Ciencias Córdoba 46: 123-427.

Schmidtlein S, Tichý L, Feilhauer H, Faude U (2010) A brute-force approach to vegetation classification. Journal of Vegetation Science 21: 1171-2010. https://doi.org/10.1111/j.1654-1103.2010.01221.x

Steinbauer MJ, Field R, Grytnes JA, Trigas P, Ah-Peng C, Attorre F, Birks HJN, Borges PAV, Cardoso P, ..., Beierkuhnlein C (2016) Topography-driven isolation, speciation and a global increase of endemism with elevation. Global Ecology and Biogeography 25: 1097-11071. https://doi.org/10.1111/geb.12469

Svenning JC (2001) On the role of microenvironmental heterogeneity in the ecology and diversification of neotropical rain-forest palms (Arecaceae). Botanical Review 67: 1-53. https://doi.org/10.1007/BF02857848

Svenning JC, Kinner DA, Stallard RF, Engelbrecht BMJ, Wright SJ (2004) Ecological determinism in plant community structure across a tropical forest landscape. Ecology 85: 2526-2538. https://doi. org/10.1890/03-0396

Tenembaum JB, de Silva V, Langford JC (2000) A global geometric framework for nonlinear dimensionality reduction. Science 290: 2319-2323. https://doi.org/10.1126/science.290.5500.2319

Tichý L (2002) JUICE, software for vegetation classification. Journal of Vegetation Science 13: 451-453. https://doi. org/10.1111/j.1654-1103.2002.tb02069.x
Walther GR, Post E, Convey P, Menzel A, Parmesan C, Beebee TJC, Fromentin JM, Zoegh-Guldberg O, Bairlein F (2002) Ecological responses to recent climate change. Nature 416: 389-95. https://doi. org/10.1038/416389a

Walther GR, Gritti ES, Berger S, Hickler T, Tang Z, Sykes MT (2007) Palms racking climate change. Global Ecology and Biogeography 16 : 801-809. https://doi.org/10.1111/j.1466-8238.2007.00328.x

Whittaker RH (1960) Vegetation of the Siskiyou mountains, Oregon and California. Ecological monographs 30: 279-338. https://doi. org/10.2307/1943563

Zak M, Cabido M, Cáceres D, Díaz S (2008) What drives accelerated land cover change in central Argentina? Environmental Management 42: 181-189. https://doi.org/10.1007/s00267-008-9101-y

Zeballos SR, Giorgis MA, Cabido MR, Acosta ATR, Iglesias MDR, Cantero JJ (2020) The lowland seasonally dry subtropical forests in central Argentina: vegetation types and a call for conservation.Vegetation Classification and Survey 1: 87-102. https://doi.org/10.3897/ VCS/2020/38013

Zuloaga FO, Morrone O, Belgrano MJ (2008) Catálogo de las plantas vasculares del Cono Sur (Argentina, Sur de Brasil, Chile, Paraguay y Uruguay). Monographs in Systematic Botany from the Missouri Botanical Garden 107: 1905-1908.

\title{
E-mail and ORCID
}

Sebastián R. Zeballos (sebazeba@hotmail.com), ORCID: https://orcid.org/0000-0003-0899-7928

Marcelo R. Cabido (mcabido@imbiv.unc.edu.ar), ORCID: https://orcid.org/0000-0001-6168-7537

Juan J. Cantero (juanjocantero@gmail.com), ORCID: https://orcid.org/0000-0003-1193-6050

Alicia T.R. Acosta (aliciateresarosario.acosta@uniroma3.it), ORCID: https://orcid.org/0000-0001-6572-3187

M. Virginia Palchetti (vpalchetti@imbiv.unc.edu.ar), ORCID: https://orcid.org/0000-0002-0442-8640

Juan Argañaraz (argajuan@gmail.com)

Paula I. Marcora (pmarcora@imbiv.unc.edu.ar), ORCID: https://orcid.org/0000-0002-3847-5971

Paula A. Tecco (paula.tecco@gmail.com)

Ana Ferreras (anitaferreras@gmail.com), ORCID: https://orcid.org/0000-0003-3739-4894

Guillermo Funes (gfunes@imbiv.unc.edu.ar)

Victoria M. Vaieretti (vvaieretti@imbiv.unc.edu.ar)

Georgina Conti (georconti@gmail.com), ORCID: https://orcid.org/0000-0002-5420-6843

Melisa A. Giorgis (Corresponding author, mgiorgis@imbiv.unc.edu.ar), ORCID: http://orcid.org/0000-0001-6126-6660

\section{Supplementary material}

\author{
Supplementary material 1 \\ Extended synoptic table \\ Link: https://doi.org/10.3897/VCS/2021/59384.suppl1
}

